\title{
The Use of Contrastive Discourse Markers in Academic Writing by English-major Saudi Female Undergraduates at Qassim University
}

\author{
Rehab Hassan Al-Owayid \\ College of Arts and Science at Unayzah, Qassim University, Qassim, Saudi Arabia
}

\begin{abstract}
Academic writing requires a skillful use of markers and linguistic features. The purpose of this quantitative study was to examine the efficacy of a one-time intervention on the use of contrastive discourse markers (CDMs) by Saudi female English major undergraduates. The present study also surveyed the opinions of writing skills instructors about CDM instruction and investigated factors that may affect the use of CDMs by undergraduates. A convenience sample of 100 students was selected from Levels 6 and 8: fifty students of each were recruited from the Colleges of Arts and Sciences in Buraydah and Onayzah cities, Saudi Arabia. Pre- and post-tests were used to collect data from student participants. Data from teacher-participants were also gathered through a questionnaire. Results of t-test analysis support the hypothesis of the significant impact of the intervention on the mean scores of the intervention group, $M=10.90 \mathrm{vs}$. $M=6.24, t(98)=12.03$, p $<0.0001$. There were no significant differences by grade level. The writing skills teachers reported that the knowledge of the different meanings of CDMs affects students' use of the markers. Factors such as the inadequate practice of critical thinking skills, the types of writing tasks, and reading-writing connection may influence students' use of CDMs. The results suggest that the knowledge of CDMs and the different meanings that they signal can improve learners to perform better.
\end{abstract}

Index Terms - academic writing, contrastive discourse markers, EFL undergraduates, semantic relationships, writing pedagogy

\section{INTRODUCTION}

Academic writing is a highly demanding task that requires a skillful use of markers and linguistic features. The incorrect use of discourse markers (DMs) may create a gap in the communication between the writer and the reader. A poor realization of the relationships that discourse markers may signal is more likely to result in an incoherent interpretation of discourse sequence (Fraser, 1997). Today, both university and college English curricula incorporate writing/composition courses as one of their indispensable components (Barnawi, 2011). Obviously, in order to reach a university level of proficiency, EFL students need to practice writing effectively (Aljafen, 2013). At times, EFL students of English at tertiary level know the rules but they perform very poorly when they try to apply them (Tahaineh, 2014). For example, they understand that contrastive discourse markers (CDMs) are used to mark contrast but, when they write, they most of the time, fail to use them in the right way. Tahaineh (2014) further stresses that Arab university EFL students encounter 'syntactic/semantic' problems in the use of DMs in spoken and written discourse. There are cases in which the CDMs are used in a repetitive way, for example, the excessive restricted use of the marker but in essay writing of Arab EFL students (Modhish, 2012). And, in other cases, CDMs are handled incorrectly, for example, the faulty use of however, but and yet by Saudi pre-university students in spoken discourse (Al-Yaari et al., 2013). The reasons for the poor performance when students use CDMs may be ascribed to three factors: the inadequate practice of critical thinking and problem solving tasks, academic writing pedagogy and teaching styles, and the kind of assignments that students receive. In this regards, Barnawi (2013) suggests that critical thinking may not be emphasized explicitly within the Saudi educational system due to traditional teaching. Many studies have reported that one reason for the problems of learning English by Arab students may result from the "poor teaching methods" (e.g., Suleiman, 1983; Ezza, 2010; Khan, 2011; Al-Khairy, 2013a; Al-Khairy, 2013b). A great number of English departments in the Arab world place great emphasis on the sentence and its structure (Ezza, 2010). The increased focus of writing instructors on grammatical rules and spelling, rather than on an idea being expressed, may lead to students being able to recognize the rules, but not knowing how to apply them (Tahaineh, 2014). In addition, Saudi EFL university students are not provided with different types of writing activities; this lack of practice may negatively affect their writing performance (Almansour \& Alshorman, 2014). Al-Khairy (2013a) asserts that English major university undergraduates are usually engaged in academic writing that is limited to "sentence-level" or at the maximum "at paragraph-level." Al-Khairy in his studies demonstrated that EFL Saudi undergraduates are not introduced to various writing tasks that promote other necessary skills, such as developing arguments and critical thinking skills. The great influx of discourse markers in academic writing and the problems which EFL students face in utilizing them have created the need for more research on DMs. The present study examined one category of English markers that express contrast, namely, contrastive 
discourse markers. Specifically, it investigated how the knowledge of CDMs affects the writing of English major Saudi female undergraduates (EMSFUs). The CDMs the present study sought to explore were but, however, instead, on the contrary and yet. The study scrutinized whether the previously mentioned markers indicated the same meaning once used.

\section{A. The Context of the Problem}

Little research has been conducted on the use of discourse markers by non-native speakers of English (Al-Yaari et al., 2013). The existing body of DM research revealed that the use of CDMs by EFL learners is limited; the research did not expand on the learners' knowledge of the meaning of CDMs (e.g. Al-Yaari et al., 2013; Daifallah\& Albesher, 2013; Modhish, 2012). In response to such a dearth in the literature on CDMs and their meaning, this study was undertaken to explore the use of CDMs by EMSFUs in academic writing. The study proceeded from Fraser's (1996) classification of DMs into four types of pragmatic markers: commentary pragmatic markers, basic markers, discourse markers and parallel markers. In a later study, Fraser (1999) identified among DMs which relate messages was a category that indicates contrast. Further, Fraser (2013) classified CDMs according to their semantic meanings. To Fraser, CDMs may signal general and specific contrastive meanings. He considered markers such as but, however, and yet as expressing general semantic relations whereas instead and on the contrary as showing a specific contrastive relation. The study was pedagogically inspired by the concern that Saudi EFL learners "use DMs randomly or for more than one purpose" (Al-Yaari et al., 2013, p. 18). Coupled with this concern was the contribution of Daifallah and Albesher (2013) that EFL Saudi students at Qassim University (QU) at the Preparatory Year Program (PYP) encounter problems in applying DMs in their writing. Another compelling trigger to conduct this study resulted from Modhish's (2012) assertion that "DMs are not given the due importance they deserve by writing instructors or EFL teachers in general” (p. 59). The study aims to present a more comprehensive framework of DMs in the Arab EFL context that builds on and attempts to develop the existing studies. It hypothesized that understanding the subtle nuances of meaning that the markers signal affects Saudi EFL undergraduates' use of CDMs in writing. The study also assumed that the problematic use of CDMs by EMSFUs may possibly be linked to a number of factors, including: inadequate practice of critical thinking skills, the academic writing pedagogy, and the kinds of writing tasks that EFLstudents are assigned.

\section{B. Research Questions and Hypotheses}

Research question 1. What percentage of Saudi female English major undergraduates at QU are unaware of the appropriate use of CDMs and thus misuse them?

Research hypothesis 1. More than $25 \%$ of Saudi female English major undergraduates at QU are unaware of the appropriate use of CDMs and thus misuse them.

Null hypothesis 1. Less than $25 \%$ of Saudi female English major undergraduates at QU are unaware of the appropriate use of CDMs and thus misuse them.

Research question 2. Is a one-time intervention presentation effective in improving students' abilities in the intervention group to properly use CDMs in the post-test?

Research hypothesis 2. The one-time intervention improves students' abilities in the intervention group to properly use CDMs in the post-test.

Null hypothesis 2. The one-time intervention does not improve students' abilities in the intervention group to properly use CDMs in the post-test.

Research question 3. Is there a difference in the use of CDMs between the experimental and control groups before and after the intervention was introduced?

Research hypothesis 3. There is a difference in the mean scores between the experimental and control groups before and after the intervention and the difference is in favor of the intervention group.

Null hypothesis 3. There is no difference in the mean scores between the experimental and control groups before and after the intervention was introduced.

Research question 4. To what extent is there a relationship between students' grade levels and the degree of change in their abilities to properly use CDMs following the intervention?

Research hypothesis 4. Grade level is related to the amount of change observed in the use of CDMs following the intervention.

Null hypothesis 4. Grade level is not related to the amount of change observed in the use of CDMs following the intervention.

Research question 5. What are the attitudes of writing skills teachers towards CDM instruction? And, is there any difference in the attitudes of writing skills teachers towards the teaching of CDMs across the two settings?

Research hypothesis 5. There are differences in the attitudes of writing skills teachers towards the teaching of CDMs across the two settings.

Null hypothesis 5. There are no differences in the attitudes of writing skills teachers towards the teaching of CDMs across the two settings.

\section{LITERATURE REVIEW}


The study of DMs has received continuing interest over the past few years (e.g., Aijmer, 2002; Al-Yaari et al., 2013; Blakemore, 1987; Blakemore, 2002; Btoosh \& Taweel, 2011; Fukushima, 2005; Hengeveld, 2012; Redeker, 1991; Schiffrin, 1987; Verdonik, Žgank \& Peterlin 2008; Wang et al., 2007; Wang, 2009; Wei, 2011; Yan, 2011; Zhuang, 2012). In the study of DMs, Schiffrin (1987) and Fraser (1999) have been the most quoted scholars. Schiffrin (1987) is credited for describing DMs in a systematic way within a theoretical model of discourse. She investigated DMs with regard to their linguistic role in achieving coherence. Unlike Schiffrin (1987), Fraser (1990) developed a more pragmatic view. He approached DMs in relation to the meaning of sentences. To Fraser, the sentence meaning consists of two parts: content meaning and pragmatic meaning. He noted that DMs contribute to the pragmatic meaning. He further claimed that DMs did not have propositional meaning, thus, when deleted, the propositional content of a sentence would not be affected. The CDM but, for instance, does not have a semantic meaning; it rather conveys "encoded clues" that signal "the speaker's communicative intentions" (Fraser, 1990; Fraser, 1996, p. 386). Fraser (1997) brought into the foreground that if a DM does not provide a relationship between discourse segments, incoherent interpretation of the discourse sequence will result. To provide some evidence, he gave the following illustrative example: “(2) a) A: Susan isn’t going to be here today. B: But [emphasis in original] Einstein liked pizza” (Fraser, 1997, para. 4). He also argued that each DM has a core meaning that is general with different nuances of meanings (Fraser, 1999; Fraser, 2006). Accordingly, the core meaning of a CDM is to express contrast and the various meaning nuances can be a contrast with a rejection of an inference or contrast and challenge of an inference. Fraser moved the analysis of DMs towards a better direction by classifying DMs into different categories among which were contrastive discourse markers. In doing so, Fraser reminded scholars that there was a gap in the existing body of research and paved the way for a rich area of investigation. Despite this recommendation, it needs to be acknowledged that most, if not all, of the available literature relevant to this study focuses on discussing DMs in general. This gap calls for a focused expansion of individual categories of DMs since each class plays an important function in the interpretation and development of a discourse. Generally, very few studies have tackled contrastive markers (Fraser, 1997; Fraser, 2013; Othman, 2000), however, the appropriate use of CDMs according to their different nuances of meanings is left unexplained. Although Fraser did not define CDMs, he provided a general framework upon which the current study is based. In terms of DM in Arab EFL literature, very few studies have investigated how CDMs are used by female university learners in academic writing in the Kingdom of Saudi Arabia (KSA; e.g., Daifallah\& Albesher, 2013). With such research gaps in the EFL literature of Arab learners on the topic of CDMs, there was every reason to conduct an informative study on the effects of CDMs and their nuances of meaning in Saudi EFL writing. The available literature EFL literature suggests a positive relationship between the use of DMs and the quality of EFL learners' discourse (Jalilifar, 2008; Daifallah\& Albesher, 2013; Tahaineh, 2014). It also stresses the relationship between DM use and language pedagogy (Aidinlou \& Shahrokhi Mehr, 2012; Modhish, 2012). In Arab EFL contexts, studies of DMs reveal that among the CDMs that Saudi students used were markers such as but, however and in contrast (Daifallah\& Albesher, 2013; Al-Yaari et al., 2013). With EFL Saudi students in mind, Daifallah and Albesher (2013) revealed that little is known about students' use of DMs in writing. In their analysis of DMs, Daifallah and Albesher (2013), pointed out the major categories of DMs according to their frequencies of use by Saudi EFL students in the test paragraphs. These categories were: adding (191 times), illustration (80 times), cause and effect (79 times) and contrast (77 times). The results of the study showed that the adding markers were the most preferred DMs by PYP EFL students. With regard to CDMs, the study reported that but, however, on the other hand, and in contrast were the most frequently employed contrastive markers. The results of their study revealed that the use of DMs by Saudi EFL students is limited. Such a finding lends great support to the study of CDMs in an EFL context. The findings of their study were in line with Al-Yaari's et al. (2013) as both sets of researchers noted that Saudi EFL learners use DMs inappropriately.

\section{OBJeCTIVES AND PURPOSE OF THIS STUDY}

Given that "CDMs vary greatly" in signaling contrastive relationships between discourse segments, this fact raises the researcher's interest to unravel this category of DMs (Fraser, 2013, p. 319). The purpose of this study was twofold: to find out if the intervention was effective in explaining the use of CDMs by EMSFUs, and to describe the views of writing skills teachers on the teaching of CDMs. More specifically, this entire venture: (a) explored the CDMs that Saudi female undergraduates use based on their performance in pre-/post-tests; (b) diagnosed the challenges experienced by the students in their attempts to use CDMs in writing; and, (c) surveyed writing teachers' perspectives on the teaching of CDMs.

\section{PROCEDURES}

To achieve the objectives of the present study, data collection occurred in four phases which were conducted in the College of Arts and Sciences of Onayzah (Setting B) first, with the same procedures being followed in the College of Arts and Sciences of Buraydah (Setting A). The collection of the pre-/post-test data began on 7th February, 2016 and was completed on 2nd March, 2016. These four phases were as follows:

1 Pre-test data. The first phase of the data collection process was a pre-test administered after obtaining informed consent from participants. The test was a 45-minute session. 
2 Intervention. In the second phase, a one-session intervention was administered one week after the pre-test to the experimental group. The allotted time for the intervention was 35 minutes and it encompassed a presentation demonstration of some of the different meanings of CDMs. Some model texts were displayed and discussed to help ensure the participants' involvement.

3 Post-test data. Immediately after the treatment session for the experimental group, both groups were tested in the post-test phase.

4 Teacher questionnaire. The fourth phase included a questionnaire that was administered to 10 writing teachers to obtain information about their opinions of CDM instruction.

\section{METHODOLOGY}

\section{A. Research Design}

The researcher of this study used a quantitative approach in which a pre- and post-test, quasi-experimental, and nonexperimental designs were utilized. The quasi-experimental design sought to determine whether a one-time intervention would influence the outcome (Creswell, 2014). Since it was not feasible to conduct a true experiment, a quasiexperiment was utilized as the closest alternative to the true experiment design (Cook \& Campbell, 1986). In this study, the intervention was limited to a non-random convenience sample of respondents who were available at the time of data collection and showed interest in participating as a treatment group. The non-experimental survey design involves one contact with writing teachers to provide an "overall picture" of their opinions about CDM instruction (Kumar, 2014). The cross-sectional questionnaire provided data on writing teachers' opinions about undergraduates' use of CDMS, CDM instruction, and the factors that may affect the use of CDMs by undergraduates.

\section{B. Population \& Sample}

The target population of this study was all female Qassim university undergraduates (Levels 6 and 8) and their female writing teachers. To provide a workable estimate of sample size, the number of participants recruited for this study was compared to the sample size of a similar study conducted by Daifallah and Albesher (2013). Based on the extant literature, it appears that the following sample size of participants was sufficient to test the research hypotheses. The present study recruited two types of participants: learner-participants and teacher-participants.

1 Learner-participants $(\mathbf{n = 1 0 0})$. To provide a representative sample group for this quantitative study, a total of 100 Saudi female English major undergraduates were selected from Levels 6 and 8 of both colleges; students at these levels have an average age between 20 and 25years. At these levels, the students have already developed their writing skills and they can compose at the paragraph level. These two specific levels were chosen to determine how well students learned how to use CDMs as they progressed to a higher level of proficiency (Table 1).

TABLE 1

\begin{tabular}{|c|c|c|c|c|}
\hline & Buraydah & & Onayzah & \\
\hline & Level 6 & Level 8 & Level 6 & Level 8 \\
\hline Experimental & 14 & 11 & 15 & 10 \\
\hline Control & 14 & 11 & 15 & 10 \\
\hline
\end{tabular}

2 Teacher-participants $(\mathbf{n}=\mathbf{1 0})$. Ten female teachers who had taught writing at each branch of Qassim university took part in this research by completing a questionnaire. The participating teachers were chosen based on expert sampling; only instructors who had the experience of teaching writing to EMSFUs were recruited. The participating teachers were Master's degree holders and teaching assistants originally from Pakistan, Saudi Arabia, Sudan, and Jordan. They had 4 to 15 years of professional experience.

\section{The Instruments of the study}

The researcher developed and used two instruments to collect research data. These included the pre- and post-tests and the teacher questionnaire. The data obtained through each tool allowed the researcher to better understand the phenomena and reach more relevant findings.

1 Pre- and post-test. In order to relate to participants' different levels of comprehension skills and improve the validity of the items, the pre/post-test was comprised of multiple choice, cloze reading, and meaning judgment items. The test was constructed by including items that had been formulated by the researcher and a reading component that was excerpted from LIKE Test Prep, (2013) a test preparation book (see Appendix A for the pre-/post-test items). The pre-/post-tests were conducted on the experimental group at two different times for 45 minutes for each test. The control group was tested in the same way as the experimental group, but they did not receive the intervention. In order to answer the test correctly, participants were expected to read, comprehend, analyze the context, use contextual clues, and judge the best CDM that would convey the required message. The results of pre-/post-tests were compared based on the standard deviation from the mean.

2 Writing skills teachers' questionnaire. The teachers' questionnaire was used to assess writing teachers' attitudes toward the teaching of CDMs. The questionnaire aimed to provide a comprehensive picture of writing teachers' 
opinions of teaching CDMs. The teachers' questionnaire included 10 Likert items that were represented on a five-point scale from strongly agree to strongly disagree (see Appendix B for the questionnaire survey items).

\section{VALIDITY \& RELIABILITY}

In an effort to minimize potential threats to the internal and external validity of this study in terms of research design, sample selection, sample size and instrumentation, the researcher undertook several steps. These included the use of a pre-/post-test design to determine the effect of the intervention and the degree of change in the scores of the experimental and control groups. The pre-/post-test design is more powerful in describing the magnitude of differences between the treatment and control groups compared to a post-test only design. In addition, the same measurement instrument was used in the pre-/post-test in the two settings to reduce instrumentation bias and the interaction of setting and treatment threats. The use of the same measurement instrument to test the experimental and control groups was also done to eliminate the threat of bias in a specific group. Avoiding the potential sampling threats to internal validity was dealt with by the selection of participants for both the experimental and control groups at the same time, and who were generally in the same age group (Levels 6 and 8), reduced the "maturation threat" to internal validity (Creswell, 2014). In an attempt to reduce threats to the external validity and allow for the generalization of data obtained from the sample to the population, the researcher drew participants from two settings and recruited more than one group. To ensure face validity of the measurements, the two instruments were sent to university experts and was amended accordingly for suitability of content and wording. A pilot test was also conducted for the two instruments in the College of Arts and Sciences at Albukayriah where participants had similar characteristics to the ones in the actual test groups.

\section{DATA ANALYSIS}

The data were organized to answer the five questions of this research study. The dependent variable under analysis in the present study was students' scores while the independent variables were the intervention and grade level. Initially, after data cleaning had been completed, descriptive statistics were calculated for the demographic data gathered from the students. The data analyses were run using IBM SPSS software (Version 21) to examine the impact of the intervention on students' scores. The first research question and hypothesis was tested through descriptive statistics in which the frequency and percentage of misused CDMs in the pre-test were calculated to assess whether the value exceeded 25\%. A one sample $t$ test was conducted by constructing a new variable for the percentage of wrong answers against the hypothesized value of 25\%. Following this, the second and third hypotheses were tested by the use of $t$ tests. The $t$ tests were used to determine if the scores between pre- and post-tests were significantly different, based on the intervention, and to identify if the change in scores pre-test to post-test represented a significant gain or loss. The fourth hypothesis was tested by an independent sample $t$ test to compare the difference of the post-test mean score between the two levels among the experimental group. The fifth hypothesis was tested through a summary of the frequencies and percentages of the 15 questions on the teacher questionnaire and then analyzed by means of a chi-square test. The significance level was set at the standard value of $p<0.05$. This value implies that if the $\mathrm{p}$-value of the results was less than .05 , then the research hypothesis is regarded as statistically significant and the null hypothesis would be rejected.

\section{RESULTS AND DISCUSSION}

The results of the data analysis for the five abovementioned research questions is organized by the measurement tools.

\section{A. Results of Pre-/Post-test}

A frequency analysis for all CDM questions were examined and the percentage of incorrect answers was reported (Table 2). The analysis showed that, on average, $48.46 \%(\mathrm{SD}=17.73$ ) of the participating undergraduates misused the markers, supporting the hypothesis that more than $25 \%$ of the participants were unaware of the appropriate use of CDMs. The frequency analysis of the percentage of incorrect answers of Part 2 (Word Choice) items shows that the percentage of incorrect use for the CDM but in this part of the test was 17\%, which was less than the hypothesized $25 \%$. A possible interpretation for this result is that students were aware of the use of but as a CDM to signal simple semantic contrast, however they were likely unaware of using the marker for expressing a degree of comparison, as was demonstrated in their incorrect answers to Part3 Q3 and Part4 Q3, with incorrect answers percentages of $42 \%$ and $75 \%$, respectively. As Table (2) illustrated, $75 \%$ of the students were not aware of the meaning of but as a CDM for expressing a degree of comparison in the following item:

In language learning, knowledge of vocabulary and grammatical rules is important. But even more important is the employment of such knowledge in the right contexts.

The above CDM in bold is used to mean:

a) Segment two is a simple contrast to segment one.

b) Segment two is an alternative to segment one.

c) Segment two is a denial to segment one to provide a correct interpretation.

d) A degree of comparison. 
The high percentage of participants who did not answer the question appropriately suggests that participants perceived the meaning of the CDM, but, as only expressing a simple contrast. The result of the analysis of the percentage of incorrect answers also reveals that in Part 4 (Meaning Judgment) of the test, students struggled to identify the meaning of however and but with 75 incorrect responses in the pre-test. On the other hand, the CDM instead (48 times) and on the contrary (54 times) were less frequently misused. These findings lent great support to Fraser's (2013) classification of CDMs into general and specific contrastive markers in terms of the relationships that they signal. As proposed by Fraser (2013), markers such as but, however, and yet impose fewer restrictions in the segments in which they occur, providing a meaning that may vary depending on the context. On the other hand, markers such as instead and on the contrary are more restrictive and signal a specific type of contrastive relationship between discourse segments that is transparent. The percentage of incorrect answers could also be an indicator that Saudi female English major undergraduates use CDMs in a random or restricted manner. This finding is similar to those of (Al-Yaari et al., 2013; Daifallah \& Albesher, 2013; Modhish, 2012) who concluded that Arab EFL learners use DMs, including markers, for expressing contrast randomly or in a limited way.

TABLE 2

FREQUENCY AND PERCENTAGE OF PRE-TEST INCORRECT ANSWERS

\begin{tabular}{lll}
\hline Questions & $\begin{array}{l}\text { Frequency of incorrect } \\
\text { answers }\end{array}$ & $\begin{array}{l}\text { Percentage of } \\
\text { Incorrect answers }\end{array}$ \\
\hline Part2 Q1 & 56 & $56.0^{*}$ \\
Part2 Q2 & 50 & $50.0^{*}$ \\
Part2 Q3 & 40 & $40.0^{*}$ \\
Part2 Q4 & 17 & 17.0 \\
Part3 Q1 & 29 & $29.0^{*}$ \\
Part3 Q2 & 36 & $36.0^{*}$ \\
Part3 Q3 & 42 & $42.0^{*}$ \\
Part3 Q4 & 71 & $71.0^{*}$ \\
Part3 Q5 & 37 & $37.0^{*}$ \\
Part4 Q1 & 48 & $48.0^{*}$ \\
Part4 Q2 & 75 & $75.0^{*}$ \\
Part4 Q3 & 75 & $75.0^{*}$ \\
Part4 Q4 & 54 & $54.0^{*}$ \\
\hline
\end{tabular}

A new variable was then created in SPSS and the percentage of wrong responses for each question was entered and run against the value of $25 \%$ in a one sample $t$ test. For the $13 \mathrm{CDM}$ questions, on average, $48.46 \%(S D=17.73)$ of the responses were incorrect, which was significantly greater than the $25 \%$ predicted at $t(12)=4.769, p<0.0001$ (Table 3 ). The null hypothesis is rejected, as more than $25 \%$ of Saudi female English major undergraduates at Qassim university were unaware of the appropriate use of CDMs in the pre-test, and thus misused them. The effect size was calculated using Cohen's $d$ which interprets effect sizes of 0.2 as small, 0.5 as medium and 0.8 as large (Cohen, 1988). The effect size was medium at $d=0.56$.

TABLE 3

ONE SAMPLE T TEST OF PROPORTIONS

\begin{tabular}{|c|c|c|c|c|c|c|c|}
\hline \multirow{3}{*}{ Measure } & \multirow{3}{*}{ Mean Difference } & \multirow{3}{*}{$S D$} & \multirow{2}{*}{\multicolumn{2}{|c|}{$95 \%$ Confidence Interval }} & \multirow{3}{*}{$t$} & \multirow{3}{*}{$d f$} & \multirow{3}{*}{$p$} \\
\hline & & & & & & & \\
\hline & & & Lower & Upper & & & \\
\hline $\begin{array}{l}\text { Percentage of pre- } \\
\text { test wrong CDMs }\end{array}$ & 23.462 & 17.73 & 12.74 & 34.18 & 4.76912 & 12 & .000 \\
\hline
\end{tabular}

To examine the efficacy of the intervention, an independent samples $t$ test. The results indicated students in the intervention group made gains that were statistically significant when comparing the pre-test $(\mathrm{M}=7.40, \mathrm{SD}=2.195)$ to post-test $(\mathrm{M}=10.90, \mathrm{SD}=1.48)$ (Table 4). Therefore, the null that the one-time intervention would not improve students' abilities to properly use CDMs in the post-test hypothesis was rejected in favor of the research hypothesis. The effect size was extremely large at $d=2.41$. This finding suggests that the one-time intervention had an impact on the mean of the intervention group. It further supports the main research hypothesis of the present study that hypothesizes the significant impact of the intervention. Consequently, an assumption can be made that awareness of the different meanings that CDMs signal may lead students to perform better in academic tasks.

TABLE 4

INDEPENDENT SAMPLES T TEST, MEAN DIFFERENCE IN POST-TEST SCORES BY GROUP

\begin{tabular}{|c|c|c|c|c|c|c|}
\hline Group & $N$ & $M$ & $S D$ & $d f$ & $t$ & $p$ (Sig.) \\
\hline Intervention & 50 & 10.90 & 1.48 & $\overline{98}$ & 12.030 & 0.000 \\
\hline Control & 50 & 6.24 & 2.30 & & & \\
\hline
\end{tabular}

A paired samples or dependent $t$ test was then conducted to compare the pre- and post-test scores within the intervention and control groups. As shown in Table (5), there were differences in the mean scores among the experimental and control groups before and after the intervention; the difference was in favor of the intervention group. The mean difference (pre-test minus post-test) of the two groups indicated a significant increase in the intervention 
group $(M=-3.500, S D=2.178)$, but there was no significant increase in the mean difference score of the control group $(\mathrm{M}=-0.240, \mathrm{SD}=2.479)$. Comparing the pre- and post-test mean scores of the two groups suggests that the intervention had a positive impact on students' scores. This is important because such findings support the research hypothesis of a difference in favor of the intervention group. Thus, the null hypothesis is rejected because the paired mean difference analysis in the intervention group revealed significant increase from the pre-test score to the post-test score for the intervention group.

TABLE 5

PAIRED SAMPLES T TEST OF STUdENTS’ DiFFERENCE SCORES FOR PRE-/POST-TEST

\begin{tabular}{|c|c|c|c|c|c|c|c|}
\hline \multirow[t]{2}{*}{ Group } & \multirow{2}{*}{$\begin{array}{l}\text { Mean } \\
\text { Difference }\end{array}$} & \multirow[t]{2}{*}{ SD } & \multicolumn{2}{|c|}{$95 \%$ Confidence Interval } & \multirow[t]{2}{*}{$t$} & \multirow[t]{2}{*}{$\overline{D f}$} & \multirow[t]{2}{*}{$p$} \\
\hline & & & Lower & Upper & & & \\
\hline Intervention & -3.500 & 2.178 & -4.119 & -2.880 & -11.361 & 49 & 0.000 \\
\hline Control & -0.240 & 2.479 & -0.944 & 0.464 & -0.684 & 49 & 0.496 \\
\hline
\end{tabular}

To examine the difference in the mean values between students of Level 6 and Level 8 with respect to their post-test scores, an independent samples $t$ test was conducted. By comparing the difference of the post-test mean score between the two levels, it was found that there was no significant difference between the mean score of Level 6 versus Level 8 . Participants in Level 6 had a relatively higher mean score in the post-test of $(M=7.41, S D=2.656)$ compared to the mean of those in Level $8(M=7.19, S D=2.412$; Table 6$)$. Therefore, the null hypothesis was not rejected in that grade level is not related to the amount of change observed in the post-test scores of the two groups. These results revealed no relationship between grade level and the amount of change in post-test average scores. Previous research by Daifallah and Albesher (2013) found that there were no differences in the use of DMs when students in the preparatory year at Qassim university moved from Level 1 to Level 2. Similarly, students in Level 6 and Level 8 of the present study did not use CDMs differently. This finding may imply that students in Levels 6 and 8 had insufficient awareness of the use of CDMs and the meanings that they signal. This finding of no difference by grade level was unexpected. The finding of insignificant variance in the post-test mean score of students in Levels 6 and 8 may further suggest that CDMs are not addressed by writing instructors resulting in a definite gap in students' knowledge of CDMs.

TABLE 6

\begin{tabular}{lllllll}
\multicolumn{7}{c}{ INDEPENDENT SAMPLES T TEST RESULTS BY GRADE LEVEL } \\
\hline Measure & $\mathrm{N}$ & $\mathrm{M}$ & $\mathrm{SD}$ & $\mathrm{df}$ & $\mathrm{t}$ & $\mathrm{P}$ \\
\hline Level 6 & 58 & 7.41 & 2.656 & 98 & .431 & 0.667 \\
Level 8 & 42 & 7.19 & 2.412 & & & \\
\hline
\end{tabular}

\section{B. Results of Questionnaire Survey}

Table 7 illustrates the frequency distribution of the teachers' views on Saudi female university undergraduates' use of contrastive discourse markers (Part 2 questions). Out of 10 teachers, 30\% $(n=3)$ indicated that students do not use CDMs frequently while another 70\% $(n=7)$ described the use of CDMs as somewhat frequent. On the other hand, $60 \%$ $(n=6)$ stated that education level affects students' use of CDMs while another $40 \%(n=4)$ of the respondents have stated an opposite view. In addition, $60 \%(n=6)$ of the participants responded that students use CDMs randomly while $40 \%(n=4)$ of the participants exhibited that students are aware of the meanings of CDMs. With regards to students' use of a restricted number of CDMs, $60 \%(n=6)$ out of the 10 participants agreed with this statement while $40 \%(n=4)$ felt that students do not use a restricted number of CDMs. Lastly, 70\% $(n=7)$ out of the 10 participants indicated their support to the statement that: "DMs are not given the due importance they deserve by writing instructors or EFL teachers in general" while $30 \%$ held the opposite opinion.

TABLE 7

FREQUENCY DISTRIBUTION FOR PART II

\begin{tabular}{|c|c|c|c|}
\hline Question & Opinion & Frequency & Percent \\
\hline $\begin{array}{l}\text { 1- How frequently do students use CDMs } \\
\text { in their writings? }\end{array}$ & Not very frequently & 3 & 30 \\
\hline $\begin{array}{l}\text { 2- Are there any differences in the way in } \\
\text { which students in Levels } 6 \text { and } 8 \text { use CDMs? }\end{array}$ & Yes (education level affects students' use of CDMs) & 6 & 60 \\
\hline \multirow{2}{*}{$\begin{array}{l}\text { 3- How would you describe students' use } \\
\text { of CDMs in their writings? }\end{array}$} & Students use CDMs randomly & 6 & 60 \\
\hline & Students are aware of the meanings of CDMs & 4 & 40 \\
\hline $\begin{array}{l}\text { 4- When students write, they tend to use } \\
\text { a restricted number of CDMs repetitively. }\end{array}$ & Yes & 6 & 60 \\
\hline \multicolumn{4}{|l|}{$\begin{array}{l}\text { "DMs are not given the due } \\
\text { importance they deserve by writing }\end{array}$} \\
\hline instructors or EFL teachers in general", & No & 3 & 30 \\
\hline
\end{tabular}

The majority of the participating teachers attributed the inappropriate use of CDMs by EMSFUs to some factors that may not be promoted in classrooms such as critical thinking skills, reading-writing connection, and interactive activities (Table 8). Clearly, there was an emphasis on the importance of critical thinking skills. All participants responded that 
critical thinking skills affect students 'application of CDMs in their writings. This finding confirms similar results by Barnawi (2011), and Ezaa (2010) who stressed the importance of developing critical thinking skills in order to alleviate EFL writing difficulties.

TABLE 8

FREQUENCY DISTRIBUTION FOR PART III

\begin{tabular}{|c|c|c|c|}
\hline Question & Opinion & Frequency & Percent \\
\hline \multirow{2}{*}{$\begin{array}{l}\text { 1. Students' critical thinking skills affect their application of CDMs in } \\
\text { their writings. }\end{array}$} & Strongly agree & 6 & 60 \\
\hline & Agree & 4 & 40 \\
\hline \multirow{2}{*}{$\begin{array}{l}\text { 2. The weak writing proficiency level of Saudi female English major } \\
\text { undergraduates can be attributed to the teachers' increased focus on } \\
\text { teaching grammar. }\end{array}$} & Strongly agree & 2 & 20 \\
\hline & Uncertain & 4 & 40 \\
\hline \multirow{2}{*}{$\begin{array}{l}\text { 3. There is a dominance of learning by memorization in the teaching in } \\
\text { Saudi English major settings that may have negative affect students' } \\
\text { writings. }\end{array}$} & Strongly agree & 5 & 50 \\
\hline & Agree & 2 & 20 \\
\hline $\begin{array}{l}\text { 4. The teaching of writing can affect Saudi EFL undergraduates' } \\
\text { reading skills. }\end{array}$ & Agree & 5 & 50 \\
\hline \multirow{3}{*}{$\begin{array}{l}\text { 5. As a writing skills teacher, I apply instructional strategies which } \\
\text { require students to read extensively for their writing class. }\end{array}$} & Strongly agree & 2 & 20 \\
\hline & Agree & 6 & 60 \\
\hline & Uncertain & 2 & 20 \\
\hline $\begin{array}{l}\text { 6. One way to develop students' use of CDMs is through engaging } \\
\text { students in argumentative writing tasks. }\end{array}$ & Strongly agree & 4 & 40 \\
\hline \multirow{3}{*}{$\begin{array}{l}\text { 8. Students' knowledge of the different meanings which CDMs signal } \\
\text { (e.g., "but" as a CDM to signal simple contrast, a denial of expectation } \\
\text { or a degree of making comparison) may affect their writings. }\end{array}$} & Strongly agree & 5 & 50 \\
\hline & Agree & 4 & 40 \\
\hline & Uncertain & 1 & 10 \\
\hline \multirow{4}{*}{$\begin{array}{l}\text { 9. CDMs as part of the grammatical structure of a text are best taught } \\
\text { in a grammar class. }\end{array}$} & Strongly agree & 1 & 10 \\
\hline & Agree & 3 & 30 \\
\hline & Uncertain & 2 & 20 \\
\hline & Disagree & 4 & 40 \\
\hline \multirow{3}{*}{$\begin{array}{l}\text { 10. Students learn how to use CDMs as they write and should not be } \\
\text { taught in any theoretical way. }\end{array}$} & Strongly agree & 5 & 50 \\
\hline & Agree & 2 & 20 \\
\hline & Disagree & 3 & 30 \\
\hline
\end{tabular}

In order to test if there were differences in the attitudes of writing skills teachers towards CDM instruction across the two settings, a chi-square Goodness of Fittest was used. The null hypothesis was not rejected since the results indicated that writing skills teachers show similar attitudes towards the teaching of CDMs across the two settings, therefore the null hypothesis was supported $\left(X^{2}=.136, d f=1, p=.712\right.$; Table 9$)$.

TABLE 9

CHI-SQUARE GOODNESS OF FIT

\begin{tabular}{ll}
\hline Chi-Square & $.136^{\mathrm{a}}$ \\
Df & 1 \\
Asymp. Sig. & .712 \\
\hline
\end{tabular}

Notes. a. 0 cells $(0.0 \%)$ have expected frequencies less than 5 . The minimum expected cell frequency is 132.0 .

\section{CONCLUSIONS \& RECOMMENDATIONS}

\section{A. Conclusions}

Discourse markers literature indicates that the use of CDMs by most Arab EFL students is limited (Al-Yaari et al., 2013; Daifallah\& Albesher, 2013; Modhish, 2012; Tahaineh, 2014). It has identified DM frequency of use by Arab EFL students, but has not identified the extent of students' knowledge of the different meanings of CDMs. The findings of the present study expanded previous studies in the area of DM use among Arab EFL students. The significance of this study lies in the recognition that knowledge of CDMs and their different meanings significantly influence how students perform academically. It may be concluded that the one-time intervention had a significant impact on students' scores since participants in the intervention group had significantly higher post-test mean scores. Further, the study revealed that it was not possible to demonstrate a relationship between changes in the mean values of the test scores and grade level. This finding suggests that Saudi EFL undergraduates may have inadequate knowledge of CDMs. This finding is consistent with the findings of the previously cited researchers (Al-Yaari et al., 2013; Daifallah\& Albesher, 2013; Modhish, 2012; Tahaineh, 2014).

The data from the writing teachers, on the other hand, revealed support for the integration of CDMs in teaching rather than teaching the markers theoretically. Implicit instruction of CDMs may be effective in developing students' use of the markers. Results have also pointed to some factors that may influence students' use and knowledge about CDMs. These factors included the inadequate practice of critical thinking skills, the types of writing tasks, and reading-writing connection. The findings of the present study have provided empirical evidence that knowledge of the different 
meanings of CDMs affects students' performance. Given that students in the present study experienced improvement after exposure to the intervention, further research is recommended to replicate the study with a different sampling technique that is more representative of the population in Qassim university.

\section{B. Pedagogical Implications}

The findings of this study identify several potential links between students' knowledge of CDMs and their academic performance. Among these is the link between an understanding of CDMs and their different meanings with stronger academic performance. The findings of the present study also offer insights into strategies that appear to positively influence CDMs instruction. In particular, this study suggests that an implicit approach to the teaching of CDMs may improve writing skills. In implicit teaching, students are provided with different writing tasks that ask them to contrast, argue, and analyze different passages. The questionnaire data and the inclusion of a cloze reading item in the test instrument all suggest that supplying students with opportunities to practice reading can help them to realize form and meaning relations, and hence improving their writing skills. This finding may imply that although there are courses on writing and others on reading skills, this fact should not by any means indicate that each skill should be taught separately. In addition, the findings imply that students should be offered opportunities that encourage them to read in order to become better writers. Writing teachers are advised to provide environments that encourage students to think critically. The finding that there were no differences by grade level may suggest the importance of addressing CDMs by writing instructors in their teaching. It also suggests areas for further research.

\section{Recommendations}

Based on the findings of the present study, several suggestions and recommendations are made for future research. First, to minimize the limitation which a one-time session may have, future studies are advised to implement several treatment sessions that may indicate the impact of the intervention at a more detailed level. A follow-up phase to the post-test is suggested to verify the impact of the intervention. Future studies are also recommended to measure the impact of the treatment on students' awareness of other CDMs. The results of the present study may be expanded by examining students' essays as a measurement tool to investigate how students employ CDMs in their writings. Second, to improve the generalizability of the results, further studies are advised to employ different sampling techniques. A study with a stratified random sample that includes participants from different settings of Qassim university or recruits Saudi EFL students across different geographic areas would potentially generate a more representative population. Replicating the study with different grade levels and including male participants would enhance generalizability. Third, a mixed method approach incorporating interviews with writing teachers and observations of real classroom practices may generate greater understanding about CDM instruction and students' awareness of the markers and the nuances of meanings which they convey. Additionally, research that incorporates the views of native English instructors is strongly recommended. Finally, writing teachers are recommended to address CDMs in their teaching practices by incorporating an implicit approach, providing activities designed to boost students' critical thinking skills, and integrating extensive reading activities.

\section{ACKNOWLEDGEMENTS}

This study endeavor is part of my master's thesis to investigate whether the knowledge of the different meanings of contrastive discourse markers (CDMs) affects English-major Saudi female undergraduates' (EMSFUs) performance.

\section{APPENDiX A. StUdents' PRe-/Post-Test}

\section{Students' Pre-post-test}

(Designed by the researcher)

This test is for educational research. Please answer all the items below.

\section{Part One: Demographic information}

Please write responses which best describe your situation

Name:

Age

Level

Name of college

Parts two, three and four below test your knowledge of contrastive discourse markers, such as instead, yet, but, however and on the contrary.

\section{Part Two: Word choice}

Please circle the suitable contrastive discourse marker (CDMs) in parentheses:

1- Crazy diets are not a solution to stay in shape (On the contrary - However - Instead), you should eat healthy and exercise regularly.

2- Today, traveling is a good (yet - on the contrary - however) expensive option for leisure.

3- Reading a book cover to cover can be a real thrill. (Contrary to - Instead - However), some books are designed to be reference sources, others may appear very technical or written in a convoluted style. 
4- Success is a very pleasant experience. It is easy to feel the pleasure of success (but- Instead -contrary to), difficult to tolerate the discomfort of failure.

Part Three: Reading The reading text below is about whether it is important to have luxurious items such as designer label clothes. Read the text carefully and fill in the blanks with the best CDMs given below:

(But, However, Instead, Contrary to/On the contrary and Yet)

There are many ways to spend our money. Some of those ways are on expensive ...... beautiful things, such as fancy cars and designer label clothes. ........, it is not important, to me, to have these items due to all the negatives that surround these luxurious items; they take away from the real important things in life, they aren't necessarily quality items, and they send a bad message to those around us.

First of all, having expensive things takes money away from the more important things. In life, we have basic needs to meet. Some examples of these needs are food, shelter and companionship.

Secondly, just because something is beautiful and expensive, it doesn't mean that item is a quality item. Let's take designer clothes for example. We go out and pay hundreds and hundreds of dollars worth of clothing that we assume is a good quality because of the name that is sewn on it. ......., within a few months, that clothing wears away just as quickly, if not quicker, than the clothing bought at a less expensive department store.

Finally, having all of these luxury items sends the wrong message to those around us. When we buy high-dollar value items, it says that we are a rich person and that we waste our money on frivolous things. Don't we want to raise our children to know that looks are not what is important in life? We should be teaching them that it is what is inside a person that counts. I am not denying that a person who looks rich will have more friends than a person who looks poor. ...... our mind and body, versus improving our clothing line and garage stock. (1)

Part Four: Meaning Judgment

Please make your judgment based on your knowledge of contrastive discourse marker (CDMs) to figure out which of the following meanings each of the CDM in bold signals. Note that segment one is what proceeds the CDM and segment two is what comes after the CDM as indicated below:

[Segment one (S1), CDM, segment two (S2)]

1- A diet full of processed food can be detrimental to your health due to the contained amounts of salt and sugar (S1). Instead, you should include more fresh fruits and vegetables (S2).

The above CDM in bold is used to mean

a) A denial of expectation in which segment two cancels or denied the interpretation of segment one.

b) Segment two is an alternative to segment one.

c) Segment two challenges segment one.

d) Segment two is factually relevant contrast to segment one.

2- Today, many people have jobs and earn a lot of money. However, most of them live in small apartments.

The above CDM in bold is used to mean

a) Segment two is a simple contrast to segment one.

b) Segment two is an alternative to segment one.

c) Segment two contradicts segment one to eliminate its assumption.

d) A degree of comparison

3- In language learning, knowledge of vocabulary and grammatical rules is important. But even more important is the employment of such knowledge in the right contexts.

The above CDM in bold is used to mean

a) Segment two is a simple contrast to segment one.

b) Segment two is an alternative to segment one.

c) Segment two is a denial to segment one to provide a correct interpretation.

d) A degree of comparison.

4- Stress is not a disease. On the contrary, it is a root cause of depression

The above CDM in bold is used to mean

a) Segment two is a simple contrast to segment one.

b) Segment two is an alternative to segment one.

c) Segment two challenges segment one to provide a correct interpretation.

d) A degree of comparison.

Thank you for your participation in this test

\section{ApPendix B. TEACHERS' Questionnaire}

(Designed by the researcher)

\section{CONTRASTIVE DISCOURSE MARKERS TEACHING SURVEY QUESTIONNAIRE}

Writing skills instructors and the teaching strategies that they employ determine to a great extent how students actually write. This applies particularly to EFL students who need an ongoing help from their writing skills teachers. This questionnaire surveys the opinions of writing skills teachers on how Saudi female university undergraduates use contrastive discourse markers (CDMs) such as, "but, however, on the contrary", etc. In addition, it invites writing skills 
instructors to express their opinions about whether undergraduates are aware of the different meanings of CDMs that can contribute to the textual, semantic, and pragmatic values of students' academic writings. The present research focuses on CDMs in terms of the frequently misused markers by Saudi female English major undergraduates at Qassim University (QU); the College of Arts and Sciences in Buraydah and the College of Arts and Sciences in Onayzah, levels 6 and 8, in academic writing and whether a one-time intervention presentation can result in a statistically significant difference in the use of CDMs between the experimental and control groups. The research will further assess how students' grade levels affect the way they use CDMs, it also highlights the different meanings of CDMs, and examines writing skills teachers' perceptions about CDMs instruction. The purpose of this questionnaire is to collect data about teachers' perceptions of the teaching of CDMs and the methods of CDMs instruction that may help EFL learners to use CDMs appropriately in academic writing

Your participation is highly appreciated and will greatly contribute to the findings of this research and their implications. Your responses will remain confidential. If there is a query you do not want to answer, simply skip it. I hope you will respond to as many queries as possible.

Part One: Demographic information

\begin{tabular}{|l|l|}
\hline Age group: & Teaching experience: \\
$\square 30-35$ years & $\square$ Fewer than 7 years \\
$\square 35-45$ years & $\square 7-15$ years \\
$\square 46$ or older & $\square 16$ or more years \\
\hline Institution: & Professional status: \\
$\square$ College of Arts and Sciences in Buraydah & $\square$ Bachelor's degree holder \\
$\square$ College of Arts and Sciences in Onayzah & $\square$ Master's degree holder \\
\hline
\end{tabular}

Part Two: The following items require your perspectives as a writing skills instructor on how Saudi female university undergraduates use contrastive discourse markers?

\begin{tabular}{|c|c|c|}
\hline Item & Question & Responses \\
\hline 1. & How frequently do students use CDMs in their writings? & $\begin{array}{l}\square \text { Never } \\
\square \text { Not very frequently } \\
\square \text { Somewhat frequently } \\
\square \text { Very frequently }\end{array}$ \\
\hline 2. & Are there any differences in the way in which students in Levels 6 and 8 use CDMs? & $\begin{array}{l}\square \text { Yes (education level affects students' } \\
\text { use of CDMs) } \\
\square \text { No (students in both levels appear to } \\
\text { use CDMs similarly) }\end{array}$ \\
\hline 3. & How would you describe students' use of CDMs in their writings? & $\begin{array}{l}\square \text { Students use CDMs randomly } \\
\square \text { Students are aware of the meanings of } \\
\text { CDMs }\end{array}$ \\
\hline 4. & When students write, they tend to use a restricted number of CDMs repetitively. & $\begin{array}{l}\square \text { Yes } \\
\square \text { No }\end{array}$ \\
\hline 5. & $\begin{array}{l}\text { Do you agree with this statement: "DMs are not given the due importance they } \\
\text { deserve by writing instructors or EFL teachers in general." (Modhish, 2012, p. 59) } \\
\text { If No, please explain: }\end{array}$ & $\begin{array}{l}\square \text { Yes } \\
\square \text { No }\end{array}$ \\
\hline
\end{tabular}

Part Three: The items below invite your opinions about CDMs instruction and the factors that may affect undergraduates' use of CDMs 


\begin{tabular}{|c|c|c|c|c|c|c|}
\hline \multirow[t]{2}{*}{$\#$} & \multirow[t]{2}{*}{ Question } & \multicolumn{5}{|c|}{ Responses } \\
\hline & & $\begin{array}{l}\text { Strongly } \\
\text { Agree }\end{array}$ & Agree & Uncertain & Disagree & $\begin{array}{l}\text { Strongly } \\
\text { Disagree }\end{array}$ \\
\hline 1 & $\begin{array}{l}\text { Students' critical thinking skills affect their application } \\
\text { of CDMs in their writings. }\end{array}$ & 1 & 2 & 3 & 4 & 5 \\
\hline 2 & $\begin{array}{l}\text { The weak writing proficiency level of Saudi female } \\
\text { English major undergraduates can be attributed to the } \\
\text { teachers' increased focus on teaching grammar. }\end{array}$ & 1 & 2 & 3 & 4 & 5 \\
\hline 3 & $\begin{array}{l}\text { There is a dominance of learning by memorization in } \\
\text { the teaching in Saudi English major settings that may } \\
\text { negatively affect students' writings. }\end{array}$ & 1 & 2 & 3 & 4 & 5 \\
\hline 4 & $\begin{array}{l}\text { The teaching of writing can affect Saudi EFL } \\
\text { undergraduates' reading skills. }\end{array}$ & 1 & 2 & 3 & 4 & 5 \\
\hline 5 & $\begin{array}{l}\text { As a writing skills teacher, I apply instructional } \\
\text { strategies which require students to read extensively for } \\
\text { their writing class. }\end{array}$ & 1 & 2 & 3 & 4 & 5 \\
\hline 6 & $\begin{array}{l}\text { One way to develop students' use of CDMs is through } \\
\text { engaging students in argumentative writing tasks. }\end{array}$ & 1 & 2 & 3 & 4 & 5 \\
\hline 7 & $\begin{array}{l}\text { Students' performance in writing changes when } \\
\text { interactive activities and technology are implemented. }\end{array}$ & 1 & 2 & 3 & 4 & 5 \\
\hline 8 & $\begin{array}{l}\text { Students' knowledge of the different meanings which } \\
\text { CDMs signal (e.g., "but" as a CDM to signal simple } \\
\text { contrast, a denial of expectation or a degree of making } \\
\text { comparison) may affect their writings. }\end{array}$ & 1 & 2 & 3 & 4 & 5 \\
\hline 9 & $\begin{array}{l}\text { CDMs as part of the grammatical structure of a text are } \\
\text { best taught in a grammar class. }\end{array}$ & 1 & 2 & 3 & 4 & 5 \\
\hline 10 & $\begin{array}{l}\text { Students learn how to use CDMs as they write and } \\
\text { should not be taught in any theoretical way. }\end{array}$ & 1 & 2 & 3 & 4 & 5 \\
\hline
\end{tabular}

Thank you very much for your time in responding to this questionnaire survey.

\section{REFERENCES}

[1] Aidinlou, N. A., \& Shahrokhi Mehr, H. (2012). The effect of discourse markers instruction on EFL learners' writing. World $\begin{array}{lllllll}\text { Journal of Education, } & \text { 2(2), } & 10-16 . & \text { Retrieved } & \text { May } & 12, & 2016\end{array}$ http://search.proquest.com/docview/1030081436?accountid=30906.

[2] Aijmer, K. (2002). English discourse particles: Evidence from a corpus. Amsterdam; Philadelphia: John Benjamins Publishing Company.

[3] Aljafen, B. (2013). Writing anxiety among EFL Saudi students in science colleges and departments at a Saudi university (Master's thesis). Retrieved May 12, 2016 from ProQuest Dissertations \& Theses Global. (UMI 1537261).

[4] Al-Khairy, M. (2013a). Saudi English major undergraduates' academic writing problems: A Taif university perspective. English Language Teaching, 6(6), 1-12. Retrieved February 02, 2016 from http://search.proquest.com/docview/1437615350?accountid=30906.

[5] Al-Khairy, M. (2013b). English as a foreign language learning demotivational factors as perceived by Saudi undergraduates. European Scientific Journal, 9(32), 365-382 Retrieved May 03, 2016 from http://eujournal.org/index.php/esj/article/download/2035/1947.

[6] Al-Mansour, N. S., \& Al-Shorman, R. A. (2014). The effect of an extensive reading program on the writing performance of Saudi EFL university students. International Journal of Linguistics, 6(2), 247-264. Retrieved May 01, 2016 from http://search.proquest.com/docview/1548423777? accountid=30906.

[7] Al-Yaari, S. A. S., Al Hammadi, F. S., Alyami, S. A., \& Almaflehi, N. (2013). Using English discourse markers (EDMs) by Saudi EFL learners: A descriptive Approach. International Journal of English Language Education, 1(2), 1-26. Retrieved September 23, 2015 from http://www.macrothink.org/journal/index.php/ijele/article/view/3058.

[8] Barnawi, O. Z. (2011). Finding a Place for Critical Thinking and Self-voice in College English as a Foreign Language Writing Classrooms. English Language Teaching, 4(2), 190-197. doi:10.5539/elt.v4n2p190.

[9] Blakemore, D. (1987). Semantic Constraints on Relevance. Oxford: Blackwell.

[10] Cohen, J. (1988). Statistical power analysis for the behavioral sciences (2nd ed.). Hillsdale, NJ: Lawrence Earlbaum Associates.

[11] Cook, T.D., \& Campbell, D.T. (1986). The causal assumptions of quasi-experimental practice: The Origins of QuasiExperimental Practice. Synthase, 68(1986), 141-180. Retrieved July 09, 2015 from http://www.jstor.org/stable/20116298.

[12] Creswell, J. W. (2014). Research design: qualitative, quantitative and mixed methods approaches (4th ed.). University of Nebraska, Lincoln: SAGE.

[13] Daifallah, A. S., \& Albesher, K. (2013). The use of discourse markers in paragraph writings: The case of preparatory year program students in Qassim University. English Language Teaching, 6(9), 217-227. Retrieved September 14, 2015 from http://search.proquest.com/docview/1459136416? accountid=30906.

[14] Ezaa, E. (2010). Arab EFL learners' writing dilemma at tertiary level. English Language Teaching, 3(4), 33-39. Retrieved January 29, 2016 from http://search.proquest.com/docview/839110883?accountid=30906.

[15] Fraser, B. (1996). Pragmatic Markers. International Pragmatics Association, 6(2), 167-190. Retrieved March 08, 2015 from http://journals.linguisticsociety.org/elanguage/pragmatics/article/view/418/350.html.

[16] Fraser, B., \& Malamud-Makowski, M. (1996). English and Spanish Contrastive Discourse Markers. Language Sciences, 18(3-4), 863-881. Retrieved March 08, 2015 from http://dx.doi.org/10.1016/S0388-0001(96)00052-6. 
[17] Fraser, B. (1999). What are discourse markers? Journal of Pragmatics, 31, 931-952. Retrieved March 09, 2015 from http://dx.doi.org/10.1016/S0378-2166(98)00101-5.

[18] Fraser, B. (2005). Towards a theory of discourse markers. Retrieved March 09, 2015 from http://people.bu.edu/bfraser/Basic\%20Introductory\%20Readings/Fraser\%20-\%202005\%20\%20Towards\%20a\%20Theory\%20of\%20DM.doc

[19] Fraser, B. (2013). Combinations of Contrastive Discourse Markers in English, International Review of Pragmatics 5(2): 318340. Retrieved August 14, 2015 from http://dx.doi.org/10.1163/18773109-13050209.

[20] Jalilifar, A. (2008). Discourse markers in composition writings: The case of Iranian learners of English as a foreign language. English Language Teaching, 1(2), 114-122. Retrieved March 17, 2016 from www.ccsnet.org/journal.html.

[21] Khan, I. A. (2011). Learning difficulties in English: Diagnosis and pedagogy in Saudi Arabia. International Research Journals, 2(7), 1248-1257. Retrieved October 10, 2015 from http://www.interesjournals.org/full-articles/learning-difficulties-in-englishdiagnosis-and-pedagogy-in-saudi-arabia.pdf?view=inline.

[22] Kumar, R. (2014). Research methodology: a step-by-step guide for beginners (4th ed.). Thousand Oaks, CA: Sage.

[23] Like Test Prep. (2013). 240 Writing Topics: with Sample Essays. Middletown, DE: CreateSpace Independent, p.52.

[24] Modhish, A. S. (2012). Use of discourse markers in the composition writings of Arab EFL learners. English Language Teaching, 5(5), 56-61. Retrieved December 11, 2015 from http://dx.doi.org/10.5539/elt.v5n5p56.

[25] Othman, N. (2000). A comparative analysis of Malay and English contrastive discourse markers. Retrieved March 27, 2015 from ProQuest Dissertations \& Theses Global. (UMI 9942397).

[26] Schiffrin, D. (1987). Discourse markers. Cambridge, UK: Cambridge University Press.

[27] Tahaineh. Y. (2014). A review of EFL Arab learners' language pitfalls and pedagogical implications. International Journal of English Linguistics 4(1), 84-102. Retrieved March 08, 2016 from http://dx.doi.org/10.5539/ijel.v4n1p84.

[28] Verdonik, D., Zagnk. A. \& Peterlin, A. (2008). The impact of context on discourse marker use in two conversational genres. Discouse $\quad$ Studies, $\quad$ 10(6), 759-775. Retrieved $\quad$ February $\quad 02, \quad 2016$ from http://journals.sagepub.com/doi/pdf/10.1177/1461445608096572.

[29] Wang, X. (2009). An investigation of Chinese English learners' use of discourse markers. (English). US-China Foreign Language, 32-36. Retrieved January 10, 2016 from http://web.uri.edu/iaics/files/11-Xiaoshi-Li.pdf.

[30] Wang, Yu-Fang et al. (2007). From informational to emotive use: meiyou ('no') as a discourse marker in Taiwan Mandarin conversation, Discourse Studies 9(5): 677-701. Retrieved January 10, 2016 from http://journals.sagepub.com/doi/abs/10.1177/1461445607081271.

[31] Wei, M. (2011). A Comparative Study of the Oral Proficiency of Chinese Learners of English across Task Functions: A Discourse Marker Perspective. Foreign Language Annals, 44(4), 674-691. Retrieved January 12, 2016 from http://dx.doi.org/10.1111/j.1944-9720.2011.01156.x.

[32] Yan, W. (2011). A Discourse-Pragmatic Functional Study of the Discourse Markers Japanese Ano and Chinese Nage. Intercultural Communication Studies, 2, 41-61. Retrieved January 12, 2016 from http://web.uri.edu/iaics/files/05YanWang.pdf.

[33] Zhuang, X. (2012). A Study of the Effects of Conjunctives on Lecture Comprehension. US-China Foreign Language, 855-863. Retrieved January 19, 2016 from http://journals.sagepub.com/doi/pdf/10.1080/10862968409547501.

Rehab H. Al-Owayid received her M.A. with honors in Applied Linguistics from Qassim University in 2017. She is currently a teaching assistant of English at the College of Arts and Science in Unayzah, Qassim, Saudi Arabia. Her research interests include second language acquisition (SLA), bilingualism, applied linguistics, pragmatics, creative writing and semantics.

Mrs. Al-Owayid worked as an EFL instructor in Buraydah Vocational and Technical Institute for one year. She is currently an academic consultant for English major students level two at the College of Arts and Science in Unayzah, Qassim, Saudi Arabia. 